\title{
Terms of Address in Pesisir Barus North SUMATERA
}

\author{
Putri MAYasari TANJUng ${ }^{1}$, Zainuddin ${ }^{2}$, AMrin \\ SARAGIH $^{3}$ \\ ${ }^{123}$ UNIVERSITAS NEGERI MEDAN
}

\begin{abstract}
The writer was found the result of this study about Terms of Address in Pesisir Barus Notrth Sumatera Kecamatan Barus, Kabupaten Tapanuli Tengah. this study aims to determine the kinds and factors of using Address Terms in Pesisir Barus community. And the data use by applying descriptive qualitative and quantitative method. The source of data was taken from the interviewing, video, recording and conversation in community. The technique for analyzing the data is descriptive qualitative research based on Wardaugh's. The result of this reserach was kinds, factors and function in Pesisir Barus Community. The most dominant kinds the terns of address are used by pesisir barus community is RT (62 times), the most dominant rarely used by pesisir barus community is KT (56 times), PN (16 times), FN (11 times), and MT (2 times), IT (4 times) is seldom used by Pesisir Barus Community. There are four kinds factors and function of the terns of address in Pesisir Barus Community can be divided as G (Gender), A (Age), FR (Family Relationship). R (Respect). With the total factors of address terms used by Pesisir Barus Community was analysis $G$ (27 times), A (28 times), FR (36 times), $R$ (60 times).
\end{abstract}

Keywords: Terms of Address, Pesisir Barus Community. 


\section{INTRODUCTION}

Sociolinguistics is concerned with investigating the relationship between language and society, with the goal being a better understanding of the structure of language and of how language functions in communication; the equivalent goal in the Sociology of language is trying to discover how social structure can be better understood through the study of language.

A recognition of variation implies that we must recognize that a language is not just some abstract object of study. It is also something that people use; following Chomsky's example, many linguistics have argued that we should not study a language in use, or even how the language is learned, without first acquiring an adequate focus on developing this latter knowledge. Instead, the linguistic should be to write grammars that will help us develop our understanding of language. This linguistic is sometimes referred to as 'theoretical linguistics,' and it has claimed a privileged position within the overall discipline of linguistics; investigation of language use has little to offer us in such a view.

Hudson (1996) has described the difference as follows; sociolinguistics is 'the study of language about society,' whereas the sociology of language is 'the study of society about language. In other words, in sociolinguistics, we study language and society to find out as much as possible about what kind of thing language is. In the sociology of language, we reverse the direction of our interest.

In the communication process, there is a time where people should greet their speaker. The way of greeting is called the terms of address. Addressing is how someone addressee another one; therefore, address is the general use of these forms, in the sense of 'the manner' of refreshing to someone in direct linguistics interaction,' has provided sociolinguistics with a significant field study (Kurt:2011). The study of language in its social context means the study of linguistics variation crucially. In different social contexts, an individual will speak in different ways; this is called stylistic variation. Moreover, speakers who differ from each other in terms of Age, Gender, Social, Ethnic group.

Addressing terms is part of greeting. Addressing the term in the greeting of the conversation shows the interest between the participants. Some people usually do addressing someone before they begin the conversation. Calling someone's name is the most common way of addressing. In address, the person must consider the classification, such as Addressing using Name, Addressing of Intimate terms, Addressing of Kinship terms, Addressing of respectful terms, and even Addressing of Mockeries (Wardaugh, 2000:264)

People should understand the language, social and cultural values of the society. They tend to think of politeness as just a matter of saying please in making the request and saying "thank you" when someone does something for us or gives us what we want. People should use addressing terms appropriate to addressing someone, and we also consider politeness in every sentence we said to not offend the partner of conversation (Artika, 2008:4).

Nababan $(1993 ; 40)$ say that the greeting system (greeting) is

someone tool speaker to express something to others. This greeting will refer to the person "you" are talking to so that the attention is fixed on the conversation system greeting in the form of words or phrases. Crystal (2008) states that "The address terms is a term used to refer to someone in a direct linguistic interaction."

Wardaugh (1993:253) Confirms that the actual rules of address in society are as complex as the society itself. Someone may address the same person in different ways. It is due to social context. In address, the speaker usually uses address terms to call each other during the conversation. Indonesia has a National language used in a formal situation, and regional language is used in informal situations that function as a symbol of the people's regional identity. These are Pesisir language, Batak language, Karo 
language, and Mandailing language, and many more. Terms of address are culture-dependent and change over time as old criteria become absolute and come to be replaced by new criteria, and other criteria and other criteria may be added to create a new system (Taavitsainen and Jucker, 2003)

\section{REVIEW OF LITERATURE}

\section{A. Terms of Address}

\section{Defenition Terms of Address}

Oyetade (1995) defines address terms as word or expressions used in interactive, dyadic and face to facesituationsto designate the person being talked to. Based on Yule (2006) assert that address terms is a word or phrase fo the person being talked to or written to. To be brief, terms of address are words or expressions used to indicate certain relation between people, or to show the difference in identity, position and social status.

People use terms of address to address each other in almost all occasions. There are three reason for using address terms. First, they are used to attract people's attention, to remind the hearer one's professional status or the relationship between the speaker and the hearer. Second, they are used to show politeness and the difference in social class and the degree of respect in certain occasions. Third, they are used to reflect social information about identity, gender, age, status and the complex social relationship of interlocutors in a speech community (Yang, 2010).

As there are so many terms of address, they cam be classified into different categoriesand criteria, different from those in this research the writer classifies it into six categories and four factors: first name, kinship terms, intimacy terms, mockery terms, respect terms, pet name. Kinship terms are terms for blood relations and for affine, indicating the relationship between one person and relatives. This kind of term is mainly used between family members, social terms of address refer to all addressing terms kinship terms, used in social communication reflecting the social relations, status and level of respect between the speaker and the addressee in the communication.

\section{a. Addressing Terms Using Name}

First, addressing terms using name is used to address other people by his/her first name and this kind is also usually used in intimate situations or person in the same status/level that is informal situation. The speaker use name to addressing the other Jack, Elizabeth, Will, etc. In north america it is usual to use first name (FN) to people you work with, regardless of how little or much you like them. And in english speaking cultures mutual FN is experienced as too familiar (Holmes 2010: 271) 


\section{b. Addressing Terms Using Kinship}

Kinship Terms is the describing how people in various part of the world refer to relatives by blood, descendent and marriage (Wardaugh 2010: 238). Kinship system are a universal feature of language, because kinship is so important in social organization. This kind of term is mainly used in social communication reflecting the social relations, status and level of respect betwen the speaker and the addressee the communication.

(Braun 1988) kinship terms are terms for blood relation and for affine indicating the relationship between one person and his relatives. This kind of terms is mainly family members.

Commonly, people use this kinds to address their family, In addressing term using kinship, the speaker used the kinship terms that is title without last name (TLN) to address the other Mom, Dad, Grandma, Cousin, etc. The speakers address the other uses the polite terms to subsitute others name in this kind of address terms.

In Pesisir Barus Community,kinship term is "Patrilineal", and kinship relationship can be evaluated based on blood and marriage are patternedor the relatives, based on family name (Marga).

\section{c. Addressing Terms Using Intimacy}

The speakers address the other uses the polite terms to subsitute others name in this kind of address terms, Darling, Dear, Sweetie, etc. The reason of addressing terms using intimacy is to show intimacy, this kind is also usually used in informal situation.

Wardaugh (2006:268) states that pet name indicates higher level of intimacy compare to the use of first name in addressing other people. The example of pet name are, Honey, Dear, Baby, Sweeetheart.

\section{d. Addressing Terms Using Respect}

in this kinds, the speakers use the title before name to address someone Mr.Jacob, Mrs, Smith, etc. This use in formal situation people tend to address someone else by their tittles.

\section{e. Addressing Terms Using Mockery}

The speaker usually addresses the other by using mockery terms in this kind fool, freak, damn, etc. (Artika, 2008:4) in other words it's including impolite addressing terms. From the example above can be a consideration that people use addresssing terms which appropriate to addressing someone and we also 
considerate politeness in every sentence we said in order not to offends the partner of conversation. This kind is also usually used in informal situation.

\section{Factors Influencing the Use of Address Terms}

Every language shows the social characters of the speaker or addresses. Furthermore, it shows the relation between them. Addressing term is one of the important tools of communication which is used society. Kinds of basic rules of addressing terms are Social Class, Age, Sex, Profession, Marital Status, Politeness and other Related aspects. The use of addressing terms depends on addresser and addressee's relationship, the social status or individual involve in the conversation, the situation and purpose of the conversation.

Wardaugh (2006) also notes that a variety of social factors usually governs our choices of terms. Among these social factors are the particular occasion, the social status or rank of the other, Sex, Age, Family Relationship, Occupational Hierarchy, Transactional Status, such as a Doctor-Patient Relationship or Priest- Penitent, Race, and the Degree of Intimacy.

Manjulakshi (2004) also notes that terms and modes of address are important in any society for purposes of identification and expression of ideas. To her, the use of these terms depends upon the social rank, age, and the sex of the persons involved in any communicative situation.

\section{a. Gender}

Gender is a factor that influence the choice of the address terms. Wardaugh (2006: 270) states that in feudel society like in Hasnapur, a wife is forced to call her husband by his first name. Moreever, she uses only pronouns to address her husband.

Gender is a source of power in the sense to some ethnic group men are considered to be powerful whereas in other ethnic group such as Pesisir Barus community put pririty to men in comparison to women.

b. Age

Age is the most potent factor in determining address relationsip. And this factor is also less important than occupational Hierarchy/Status. It never happened that younger person had higher-status person used TLN to the older lower-status person and received FN in return (Fasold:2001).

\section{c. Social Status/Respect}

In social relationship, the status and intimacy between interlocutors determine the choice of address forms, however, in certain cultures, the selection of address form is also connected to the culture's rules of politeness. In English culture, the most common forms of address are first name and Title + Last name 
(Brown and Ford, 1961.

People can find many forms of address term used. In relax situation, someone often calls a friend with his Nickname, such as Tom for Tommy or Mickey for Michael. However, in other formal situation, people tend to address someone else by their titles like Mr, Mrs and other names which refer to the profession they have. Besides, the addresses of My love, My Dear, or tittle one are usually used to show the intimate relation between the addresser and addressee.

\section{d. Family Relationship}

According to Wardaugh (2006: 271), family relationship will influence change will influence the choice of the address terms. The confusion may arise when someone has to address his/her Father in law. Addressing father in law as "Mr. Smith" is sometimes felt to be away too formal, only "Smith" is too familiar, and "Dad".

\section{RESEARCH METHODOLOGY}

In doing this research, the researchers was used Descriptive Qualitatives design, because the researchers intends to describe the kinds of address terms and describe factor that influence using address terms in Pesisir Barus Community, and also find out reason using address terms. Lincoln and Guba (1985) in Ary (2000:426) state that a Qualitative researcher choose for investigation as the focus of inquiry.

\section{FINDINGS and DISCUSSIONS}

\section{Findings}

After doing analyzing data and explain kinds, factors and function that influence the address terms by Pesisir Barus Community in North Sumatera. The researcher was found concluded that Pesisir Barus arbitrary to Address situation in someone certain. And also there are several factors that affect it all. There are some kinds, factors and function of address terms that they used and it is influenced of some factors.

In the data analysis there were only six kinds address terms used by pesisir barus community:

\section{a. Kinds of Address Terms}

There are six kinds of the terms of address by wardaugh's theory they are first name (FN), title plus last name (TLN), title (T), last name (LN), pet name (PN), and kinship term (KT), from six kinds, there were six kinds they were, FN, PN, MT, RT, KT, IT. With the total kinds of address terms used by pesisir Barus Community in interviewing are 151 data. The most dominant kinds the terns of address are used by pesisir barus community is RT (61 times), the most dominant rarely used by pesisir barus community is KT (56 times), PN (16 times), FN (11 times), and MT (2 times), IT (2 times) is seldom used by Pesisir Barus Community. So it 
means that community in there more used terms of address RT and KT for daily use.

\section{b. Factors of Address Terms}

In the data analysis there were only four factors and each factors of address terms used by Pesisir Barus Community:

\section{Gender}

Gender is a factor that influence the choice of the address terms. The fctors influenced who is the addresseeror man/woman. This is some example factors influenced by gender, as follows:

- Manga dakUngonkudung rambut tu e

- pature dulu kandang surati nan di balakkang tu Buyung

Factors that influence the terms of address are G. Ungon is addressing to daughter, Buyung is addressing to brothers.

2. Age

Age is the most potent factor in determining address relationsip. And this factor is also less important than occupational Hierarchy/Status. That influenced by Age, as follows:

- Lamak bana gule paranci Ucci ko da

- Pabilo anyo munak mancalik Angku tu dari samalam ala kambuh panyakkik nyo

Factors that influence the terms of address are A. Ucci is addressing to Grandmothers, Angku is addressing to grandfathers.

\section{Family Relationship}

Family relationship is relation between family one another, and family relationship there are also different address terms, that influenced by FR, as follows:

- Mangapo dak juo Mak'tuan ko datang mangantekan karambi mudo tu

- Ala barubek anyo takananyo Mak'uwo ko tadin

Factors that influence the terms of address are FR, mak'tuan is addressing to man from family mother, mak'uwo is addressing to woman from family father.

\section{Social Status/Respect}

Social status/Respect is In social relationship, the status and intimacy between interlocutors determine the choice of address forms, however, in certain cultures, the selection of address form is also connected to the culture's rules of politeness. that influenced by SS/FR as follows:

- Pabilo anyo Tuan Kadi tu datang ka rumah anak daro tu

- Ala gaek bana Induk Inang ko da tapi tatap cogah bana di liek 
Factors that influence the terms of address are SS/R, tuan kadi is addressing to man, induk inang addressing to woman.

Table 4.2. Factors that Influence the Terms of Address

\begin{tabular}{|l|l|l|l|}
\hline NO & $\begin{array}{l}\text { Factors that influence the Terms } \\
\text { of Address }\end{array}$ & Number & Persentage \\
\hline 1 & Gender (G) & 27 & $17,88 \%$ \\
2 & Age (A) & 28 & $18,54 \%$ \\
3 & Family Relationship (FR) & 36 & $23,84 \%$ \\
4 & Respect (R) & 60 & $39,73 \%$ \\
\hline \multicolumn{2}{|l|}{ Total } & 151 & \\
\hline
\end{tabular}

\section{Discussions}

With respect to the interviewing of this study, the following points could be found some kinds and factors. The attempt of the researcher concerning types of the address terms in pesisir Barus Community can be describing kinds of used addressing in some situation. And also the researcher conducted interview with the one of community and found sources understands about the thesis in cnducting researcher also uses step by step to collect the data about address terms by Pesisir Barus Community in north Sumatera, Kecamatan Barus.

In dominant kinds of address terms between First Name, Pet Name, Kinship terms, Mockery terms, Intimacy terms, Respect terms is Kinship Terms because Kinship Terms the most often used in daily calls in environment. Kinship terms is one of calls in family members who have family ties. All of kinds from address terms can be seen how the different uses of each address terms and most rarely used is a call Mockery Terms. Mockery Terms is one of call which coarse or impoliteness spoken to family or others people. The reason that the study developed six categories of address terms in Pesisir Barus North Sumatera language by no means support the equivalence of the importance and frequency of the categories. Each category has its special usage for particular people and under certain condition.

To address one another, Pesisir Barus interlocutors are likely to make use of different techniques. This open variety provides the Pesisir Barus speaker with an extensive range of terms to address the recipients. Employment of a proper address terms is affected by factors as age, gender, personality, social status, religious orientation, Family Relationship, the degree of respect, familiarity, formality, and intimacy between the interlocutors. And there are also some factors and function in address terms is Gender, Age, Family Relationship, Respect and most dominant the used in Pesisir Barus is Respect (R) because in Pesisir Barus people often call Respect to those around him/her even through they is not family but they call people with respect. Most like factors age, gender, Family Relationship often used in the language of the closest family. From the explanation about Address Terms the writer condeucted to discussion because material research more specific 
and suitable an armful in discussion.

This study had shown that there were six kinds of addressing terms used in Pesisir Barus by the characters, (1) addressing using name (First Name, full name and last name). (2) addressing using intimacy, (3) addressing using kinship, (4) addressing using mockery, (5) addressing using respect, (6) addressing using pet name. The finding showed some pattern in the addressing terms. Some of the findings were in accordance with the previous findings in previous studies but some of the unique addressing term were also found.

The addressing of addressing is to mantain social relationship between addresser and addresseein sociey. Greetings need to be done by both participant to start conversation shows the interest between the participants. Some people usually do addressing someone before they begin the conversation. Calling someone name is the most common way of addressing. In addressing, the person must consider the classification, such as addressing of respectful terms and even addressing of mockeries. People can find many forms of addressing term used, in the formal situation, people usually address someone else by their titles.

The reason that the study developed six categories language and four factors certain function in address terms the equivalence of the importnce are kinds of the catedorieseach category has its special usage for particular people and under certain condition. Developing new terms and banding some another over time which is the characteristic of dynamic languages show that Pesisir Barus Community language is dynamic enough to comply with the sociocultural changes in its speech communities. One more points of address terms has to address unique to call someone in each person and also can be different in address terms as follows, Gender, Age, Family Relationship, Respect, so that clearly can be clearly in Appendices.

\section{CONCLUSIONS AND SUGGESTIONS}

\section{Conclusions}

The data clearly indicate that besides interpersonal relationship,context has a substantial effect on the choices of terms of address, both in Pesisir Barus. A number of factors such as who, whem, where, to whomthe form is used, and with what kind of intentions have a significant influence. Therefore, the choice of term of address cannot be determined without considering the concrete context in which the address forms are used.

Based on data and data analysis in chapter IV about terms of address by pesisir barus community. The first conclusion is concerned with kinds of the terms of address by Pesisir Barus Community.the second conclusion is related to factors and function that influenced the terms of address by Pesisir Barus Community, as follows:

1. There are six kinds of the terms of address by wardaugh's theory they are first name (FN), title plus last name (TLN), title (T), last name (LN), pet name (PN), and kinship term (KT), from six kinds, there were six kinds they were, FN, PN, 
MT, RT, KT, IT. With the total kinds of address terms used by Pesisir Barus Community in interviewing are 151 data. The most dominant kinds the terns of address are used by Pesisir Barus community is RT (61 times), the most dominant rarely used by Pesisir Barus community is KT (56 times), PN (16 times), FN (11 times), and MT (2 times), IT ( 2 times) is seldom used by Pesisir Barus Community. So it means that community in there more used terms of address RT and KT for daily use.

2. There are four kinds factors and function of the terns of address in Pesisir Barus Community can be divided as G (Gender), A (Age), FR (Family Relationship). R (Respect). With the total factors of address terms used by Pesisir Barus Community was analysis G(27 times), A (28 times), FR (36 times), R (60 times) . it means that all factors were used by Pesisir Barus Community, and then based on the data, factor and function that influenced of Pesisir Barus Community is usually R and FR or by the relatives in there.

\section{Suggestion}

After collected and analyzed the data about Terms of Address in North Sumatera, some suggestion are given as follows:

1. The researcher suggest to reader and student who want to know about Pesisir language and culture, especially Barus community who doesn't know about Pesisir Barus language anymore, it is be better to learn through because very interesting and unique start from kinds and used name for women and men because the language almost similar with Minangkabau language.

2. It is suggested that the reader of this thesis is important to know what kinds of the terms of address are used by Pesisir Barus Community and what factors and functions influenced the terms of address by Pesisir Barus Community, and also how the different used terms of address in each person between women and men. especially in Community Barus.

3. For further researchers, who wants to use of address terms usage as the object of the researher or for researcher who wants to analyze of address terms from different perspective. Terms of address can be found in every language, it's not only Pesisir Barus language but also the other language in each area.

\section{REFERENCES}

Artika, Ratna P. 2008. An Analysis on the use of intimate address system in thedrama fims (A Sociolinguistics Approach). Unpublished Research 
Paper.Surakarta: Muhammadiyah University Of Surakarta.

Brown, Roger, and marguerite ford 1961 “ Address In american English” journalof Abnormal and Social Psychology, 62 375-85.

Braun, Friederike 1988. Terms Of Address: problems of patterns and usage invarian languages and cultures, Contribution to the Sociology of Language, 50, Berlin: Mouton de Gruyter.

Chaika, Elaine, 1982, Language: the social mirror.Social Edition. Bostom,Massachusetts USA:

Heive PublisherHudson, R. A (1996).Sociolinguistics. 2nd edn. Cambridge: Cambridge University Press.

Chaika, E. (1982). Language the social mirror, rowley, MA: Newbury House.

Dian Muhammad rifai, S. t. (2016). A Sociolinguistics analysis of addressingterms used in tangled movie manuscript. Jurnal Penelitian Humaniora, 17,123-134.

Dunkling, lesile 2007. Dictionary of epithest and terms of address. New York:Roudledge.

Holmes,Janet. 2010. An Introduction to Sociolinguistics. England: PearsonEducation limited

Kurt, Danziger. 2011. Interpersonal Communication. Australia: Pergamon PressLincoln and Guba in Ary. 2002. Introduction to Research in Education. USA:Tandra Jorgense

Manjulakshi, L. (2004): Modes of address in kanada: A sociolinguistics studyoflanguageuseinmysoredistrictavailableat:http://www.languag

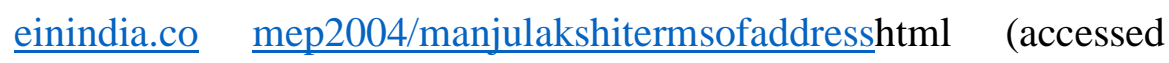
september 2008)

Nababan, P.W.J. 1993. Sosiolinguistik: Sastra Pengantar, Jakarta: Gramedia

Oyetade, S. O. (1995). A Sociolinguistics analysis of Adrres Terms in Yoruba.Language in society, 24 (4), 515-553.

Taatvitsainen, I \&Jucker, H. A (2003).Diachronic perspective on address termsystems. Philadephia: John Benjamin North America. 
Thomas And Wareing. 2001. Language, Society, and Power. Usa: Tj InternationalLtdAspect.Journal of language teaching and Research, 1(5), 738-742.

Wardaugh, Ronald. 2010.An Introduction to Sociolinguistics. United Kingdom:Blackwell. Wardaugh,

Ronald. 2006.An introduction to Sociolinguistics. Massachusetts:Blackwell Xianghong, Cao, 2006. A Pragmatic Analysis of Addressforms in ChineseFamilyand non-family letters. China media research, 2 (1) : 60

Qin, X. (2008). Choices in Terms of A ddress: A Sociolinguistics Study ofChinese and American English Practices. Proceedings of the 20th NorthAmerican Conferenceon Chinese Linguistics (NACCL-20), 1, 409- 421.

Yule, George. 2006. Pragmatik (Terjemahan Indah Wahyuni), YogyakartaPustaka Pelajar.

Yang chunli. 2010. Translation of EnglIsh and Chinese Addressing Terms fromThecultural aspect. Journal of Language Teaching and Research 4 (1):738-742. 